\title{
OCENA PRZYCZYN USZKODZEŃ I METODA NAPRAWY ELEMENTÓW POMOSTU MOSTU KRATOWNICOWEGO
}

\begin{abstract}
Artykuł dotyczy zagadnień związanych z pracą statyczną poprzecznic w kolejowych mostach stalowych $\mathrm{z}$ otwartym pomostem. Przedstawiono problem zwiększonego wytężenia i odkształcenia poprzecznic od sił poziomych, wywołanych zmianą długości pasów dźwigarów głównych i sił hamowania pojazdów. Na przykładzie mostu kolejowego przez rzekę Wartę w Sieradzu omówiono charakterystyczne dla tego zjawiska uszkodzenia elementów jezdni mostu oraz sposób ich naprawy, z zastosowaniem indywidualnie zaprojektowanych łożysk, umożliwiających przegubowo przesuwne oparcie podłużnic na poprzecznicach.
\end{abstract}

Słowa kluczowe: most kratownicowy, przesuwne oparcie podłużnic, łożyska stalowe

\section{Wprowadzenie}

Otwarte pomosty $\mathrm{w}$ mostach kolejowych, gdzie nawierzchnia w postaci szyn na podkładach drewnianych jest mocowana bezpośrednio do dźwigarów głównych lub do podłużnic, były powszechnie stosowane od początku rozwoju kolejnictwa aż do lat 60-tych, 70-tych XX wieku. W przypadku wiaduktów, gdzie pod obiektem odbywał się ruch pojazdów i pieszych stosowano pomosty zamknięte, szczelność uzyskując przez stosowanie blach nieckowych lub cylindrycznych, na których układano nawierzchnię na podkładach i podsypce tłuczniowej. Pomosty otwarte wykonywane były w dwóch zasadniczych rozwiązaniach konstrukcyjnych, z mostownicami układanymi bezpośrednio na pasie górnym dźwigara, najczęściej w mostach belkowych, małych i średnich rozpiętości oraz $\mathrm{z}$ mostownicami układanymi na podłużnicach, w rozwiązaniach $\mathrm{z}$ poprzecznicami, pracujących w układzie rusztu. Ten drugi typ układu stosowany był w obiektach większych rozpiętości, często w mostach kratownicowych, zarówno z jazdą górą, jak i dołem.

\footnotetext{
${ }^{1}$ Mariusz Hebda, Politechnika Krakowska, Katedra Budowy Mostów i Tuneli, ul. Warszawska 24, 31-155 Kraków; tel. 1286282113; mariusz.hebda@pk.edu.pl
} 
Obecne przepisy kolejowe [1] i [2] nie zezwalają na stosowanie w nowych i modernizowanych obiektach mostowych pomostów otwartych, zalecając przy tym nawierzchnię na podkładach i podsypce tłuczniowej. Stosuje się zatem pomosty zamknięte, najczęściej współpracujące z dźwigarami głównymi w przenoszeniu obciążeń, w postaci płyt żelbetowych lub stalowych płyt ortotropowych. Płytę kształtuje się w formie tak zwanego koryta balastowego, w którym umieszcza się podsypkę tłuczniową. Wyjątkowo, w uzasadnionych przypadkach dopuszcza się stosowanie nawierzchni bezpodsypkowych, mocowanych bezpośrednio do konstrukcji, takich jak nawierzchnie na podkładach blokowych, lub tak zwanej szyny w otulinie.

Pomimo stopniowego wycofywania z użytkowania obiektów z pomostami o jezdniach otwartych, mostowcy wciąż bardzo często spotykają się w swojej praktyce z tego rodzaju konstrukcjami, z uwagi na ich dużą liczbę wśród eksploatowanych obiektów mostowych. Spośród wszystkich mostów kolejowych eksploatowanych obecnie w Polsce 42,0\% stanowią mosty stalowe, a aż 76,3\% ogólnej liczby obiektów to konstrukcje starsze niż 50 lat [3], co dobrze obrazuje skalę występowania obiektów ze starymi rozwiązaniami pomostów. Obiekty te są systematycznie przebudowywane i modernizowane, w ramach inwestycji szeroko prowadzonych w ostatnich latach na kolei. Nawierzchnia na mostownicach jest stopniowo zastępowana nawierzchnią na podkładach i podsypce tłuczniowej, nie dzieje się tak jednak na wszystkich obiektach. Jeżeli prace prowadzone są w ramach rewitalizacji linii i zuwagi na dobry stan techniczny, a także odpowiednią nośność dźwigarów głównych ograniczają się tylko robót remontowych, często pozostawia się rozwiązania z otwartym pomostem. Wymianie podlegają wtedy tylko mostownice i ewentualnie naprawiane są elementy jezdni jak poprzecznice, podłużnice, czy też ich połączenia. Jedynym zaleceniem wynikającym z [1] i [2] jest wtedy konieczność oparcia nowych mostownic na podłużnicach lub na pasach dźwigarów głównych za pośrednictwem podkładek centrujących.

Jak zatem widać znajomość rozwiązań konstrukcyjnych, a także zasad pracy statycznej elementów jezdni w starszych mostach jest wciąż potrzebna, szczególnie wśród młodego pokolenia inżynierów mostowych. Poniżej przedstawiono opis remontu mostu kratownicowego z otwartym pomostem z jazdą górą, w którym uszkodzeniu uległy elementy pomostu. Głównym powodem uszkodzeń był charakterystyczny dla konstrukcji tego typu problem przeciążenia poprzecznic na skutek sztywnego połączenia ich z podłużnicami.

\section{Praca statyczna poprzecznic}

Poprzecznice pracują głównie na obciążenia pionowe, pochodzące od ciężaru własnego konstrukcji i elementów wyposażenia oraz od obciążeń użytkowych, które są na nie przekazywane w miejscach oparcia podłużnic. Obciążenia te wywołują pionowe zginanie poprzecznic, a wartości sił przekrojowych wywo- 
łanych tym obciążeniem można w przypadku poprzecznic w mostach dwudźwigarowych wyznaczyć z prostego modelu belki swobodnie podpartej o rozpiętości teoretycznej równej rozstawowi dźwigarów głównych [4], a w mostach wielodźwigarowych z modelu belki ciągłej opartej na dźwigarach lub z przestrzennego modelu rusztowego, uwzględniającego wzajemne sztywności układu. Schemat belki ciągłej będzie właściwy w przypadku małej sztywności poprzecznic w stosunku do dźwigarów. Stosowany najczęściej dwuteowy kształt przekroju poprzecznego poprzecznic, wykonanych jako blachownica spawana lub nitowana, ze stosunkowo smukłym środnikiem, wynika z doboru odpowiedniego wskaźnika wytrzymałości na zginanie w płaszczyźnie pionowej.

Gdy poprzecznice są połączone z podłużnicami i dźwigarami w sposób sztywny, mogą doznawać również znacznych oddziaływań poziomych, pochodzących od sprężystej współpracy podłużnic z dźwigarami oraz w omawianych tutaj mostach kolejowych z pomostem otwartym, również od sił hamowania taboru kolejowego.

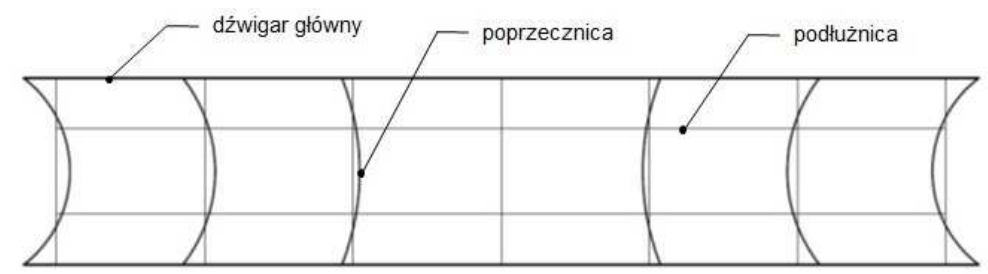

Rys. 1. Deformacja pozioma poprzecznic

Fig. 1. Horizontal deformation of floor beam

Naprężenia i przemieszczenia poziome poprzecznic mogą osiągać tutaj znaczne wartości, potęgowane małą sztywnością poziomą wysokich dwuteowych przekrojów. Problem ten jest dobrze rozpoznany i opisany w literaturze, na przykład w [4]. Znaczne obciążenia poziome poprzecznic pochodzą od zmiany długości pasów dźwigarów, na skutek działających obciążeń pionowych. Pasy dźwigarów głównych ulegają skróceniu górą i wydłużeniu dołem. Odkształceniom podobnym podlegają również podłużnice, ale z uwagi na różne położenie osi obojętnych dźwigarów i podłużnic, w znacznie mniejszym stopniu niż dźwigary. Osie bezwładności podłużnic i dźwigarów są znacznie od siebie oddalone w mostach o dźwigarach kratownicowych z jazdą górą lub dołem i tutaj efekt ten jest znacznie bardziej odczuwalny niż w mostach belkowych, gdzie podłużnica sytuowana bywa zazwyczaj między pasem górnym i dolnym dźwigara, blisko jego osi bezwładności. Efektem takiej pracy są dodatkowe naprężenia w podłużnicach, ściskające przy układach z jazdą górą i rozciągające w układach z jazdą dołem. Naprężenia te nie są jednak duże, wynoszą do około 1,5 $\div$ 4,5 MPa [4], co pozwala zaniedbać je w praktycznych obliczeniach inżynierskich. Zdecydowanie większe efekty obserwowane są w poprzecznicach, w których omawiany 
wpływ różnicy wydłużeń powoduje ich poziome zginanie, tym większe im dalej poprzecznica znajduje się od środka przęsła (rys. 1.). Poprzecznica środkowa nie jest zginana wcale, a największemu zginaniu poddane są poprzecznice podporowe. Naprężenia, które towarzyszą temu zginaniu osiągają duże wartości, mogące w zależności od długości przęsła, znacznie przekraczać $100 \mathrm{MPa}$ [4]. Na skutek deformacji poziomej poprzecznic może też dochodzić do uszkadzanie się połączeń podłużnic z poprzecznicami, zwłaszcza w rozwiązaniach, gdzie podłużnica oparta jest bezpośrednie na pasie górnym poprzecznicy.

Aby ograniczyć wpływ omawianych obciążeń na pracę statyczną poprzecznic, szczególnie w dłuższych mostach, można zastosować dwa charakterystyczne rozwiązania konstrukcyjne. Pierwsze polega na przerwaniu ciągłości podłużnic w środku rozpiętości mostu, co powoduje zmniejszenie odcinków dźwigarów na których sumują się odkształcenia działające na poprzecznice i przez to zmniejsza się wielkość tych oddziaływań. Rozwiązanie to jest stosunkowo proste i daje dobre efekty, jednak wymaga zastosowania dwóch tężników hamownych, po jednym dla każdego z odcinków niezależnie pracujących podłużnic (rys. 2a). Drugi sposób polega na połączeniu podłużnic z poprzecznicami w sposób przegubowo przesuwny, co całkowicie eliminuje przekazywanie na poprzecznice oddziaływań poziomych pochodzących od zmiany długości dźwigarów i jednocześnie daje możliwość stosowania tylko jednego tężnika hamownego na długości przęsła. Tężnik taki zlokalizowany jest w środku rozpiętości w miejscu stałego podparcia podłużnic (rys. 2b)

a)

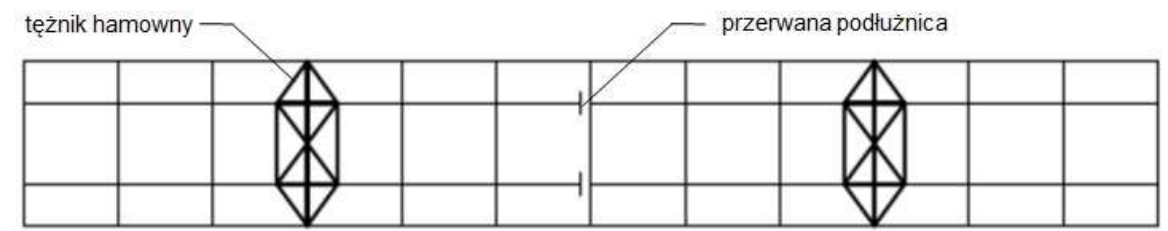

b)

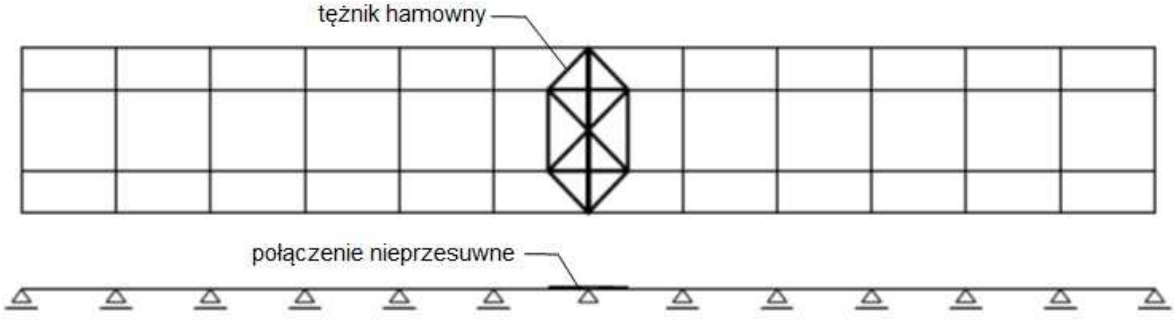

Rys. 2. Ograniczenie zginania poprzecznic przez rozcięcie podłużnic (a) i przez przesuwne oparcie podłużnic na poprzecznicach (b)

Fig. 2. Limiting bending of floor beams by cutting stringers (a) and by sliding support of stringers on floor beams 
Należy zaznaczyć, że przegubowe połączenie poprzecznic z podłużnicami było dopuszczone przez wycofaną normę do projektowania mostów stalowych [5] tylko w przypadku, gdy podłużnice układane były na poprzecznicach. Podobnie dopuszczalne było przegubowe połączenie poprzecznic z dźwigarami głównymi, gdy poprzecznice układane były na dźwigarach. Pozostałe przypadki połączeń belek podłużnych z poprzecznymi i poprzecznych z dźwigarami należało wykonywać jako stałe, nieprzesuwne, z zapewnieniem ciągłości belek łączonych. Obowiązujące obecnie Eurokody nie podają żadnych zaleceń co do kształtowania elementów w stalowych pomostach belkowych.

Jeszcze innym sposobem, stosowanym w celu ograniczenia niekorzystnych wpływów pochodzących od różnic przemieszczeń dźwigarów i podłużnic był sposób montażu konstrukcji, w którym stałe połączenia podłużnic z poprzecznicami wykonywano po zdjęciu konstrukcji z rusztowania, gdy wyzwoliły się odkształcenia dźwigarów głównych. Do tego czasu stałe połączenie wykonywano tylko na jednym końcu podłużnicy. Uzyskiwano wówczas ograniczenie zginania poziomego poprzecznic tylko od obciążeń użytkowych i elementów wyposażenia obiektu.

\section{Opis konstrukcji mostu}

Opisane powyżej efekty związane z deformacją poziomą poprzecznic obserwowano na moście kolejowym w ciągu linii nr 14 Łódź Kaliska - Tuplice przez Wartę w Sieradzu (rys. 3.). Most składa się z dwóch bliźniaczych konstrukcji w torze $\mathrm{nr} 1 \mathrm{i} \mathrm{nr}$ 2. Każda $\mathrm{z}$ nich to siedem wolnopodpartych konstrukcji stalowych z jazdą górą, opartych na kamienno-betonowych przyczółkach i filarach (rys. 4.).

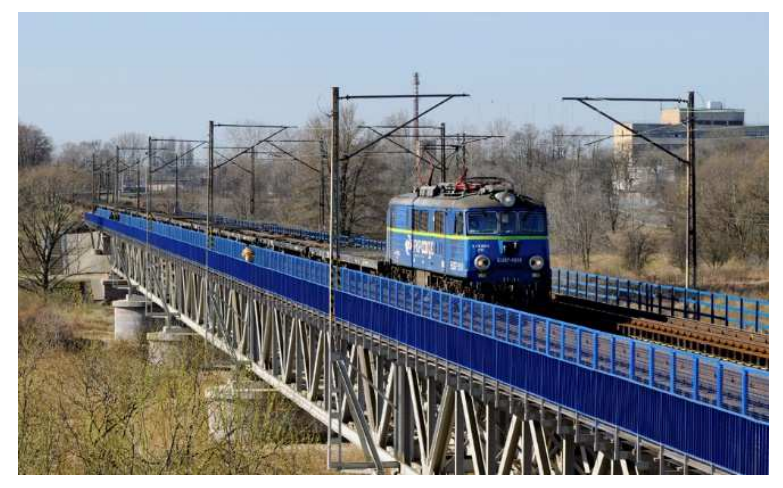

Rys. 3. Widok ogólny mostu

Fig. 3. View of the bridge

Przęsła skrajne, stanowią dwudźwigarowe blachownice nitowane o pasach równoległych ze środnikiem wysokości 1,30m o rozstawie $1,90 \mathrm{~m}$ i rozpiętości 
teoretycznej 13,50m. Blachownice opierają się na przyczółkach za pośrednictwem łożysk stałych i na filarze poprzez stalową podporę wahaczową. Blachownice posiadają pionowe i poziome stężenia poprzeczne. Przęsła środkowe są wykonane $\mathrm{w}$ postaci dwudźwigarowych kratownic dziesięciopolowych o pasach równoległych ze skratowaniem typu „N”. Konstrukcje o wysokości 4,50m i długości pola 4,40m mają rozpiętość teoretyczną 44,40m.

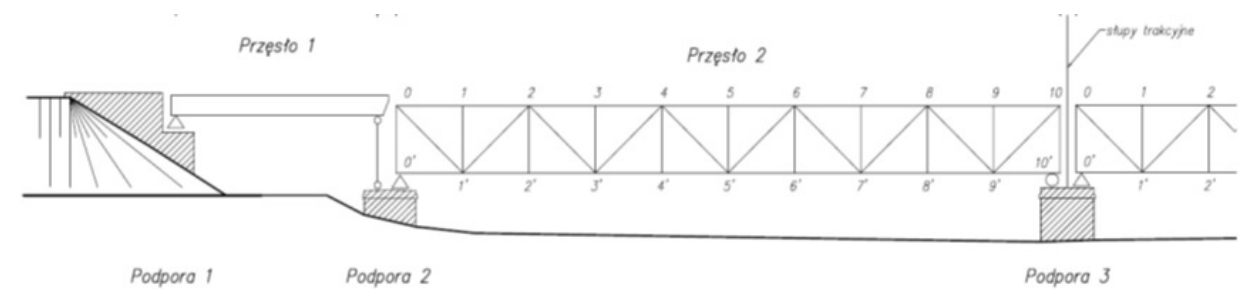

Rys. 4. Schemat konstrukcyjny mostu

Fig. 4. Structural system of the bridge

Na moście daje się wyróżnić trzy typy dźwigarów kratowych, różniących się datą powstania, przekrojami prętów głównych i przyjętym systemem skratowania wiatrownic. Przęsła typu A, nitowane, zostały wybudowane w czasie II wojny światowej przez niemiecką firmę Kruppa. Przęsła typu B, nitowane, wybudowane w 1915 roku, częściowo zniszczone w czasie II wojny i odbudowane w 1946 roku. Przęsła typu C, spawano-nitowane, wybudowane w latach 1945-60.

W przęsłach skrajnych mostownice opierają się bezpośrednio na pasach dźwigarów blachownicowych. W przęsłach kratowych mostownice oparte są bezpośrednio na podłużnicach, które połączone są nieprzesuwnie z górnymi pasami poprzecznic i połączone między sobą stężeniami poziomymi (rys. 5.).

Przed remontem mostu w awaryjnym stanie znajdowało się wiele elementów pomostu. Najgroźniejsze uszkodzenia występowały w węzłach połączeń podłużnic z poprzecznicami. Były to rozległe pęknięcia blach pionowych przypór węzłowych, duże ubytki korozyjne w kątownikach łączących blachy pionowe przypór z poprzecznicami, wiele rozluźnionych nitów w połączeniach kątowników poziomych z pasami poprzecznic, nie przyleganie dolnych pasów podłużnic do górnych pasów poprzecznic. Dodatkowo stwierdzono brak wymaganej nośności na zginanie poprzecznic w kierunku poziomym. Bezpośrednią przyczyną uszkodzeń i przeciążenia poprzecznic były siły poziome wygenerowane w węzłach poprzecznic z podłużnicami od różnicy odkształceń poprzecznic i dźwigara. Rozluźnienie części połączeń, pierwotnie sztywnych, bardzo niebezpieczne dla prowadzonego ruchu pociągów, zadziałało jednak korzystnie na poprzecznice. Nastąpiło samoistne wymuszenie przesuwnego schematu oparcia podłużnic i spadek sił poziomych oddziaływujących w węzłach. 


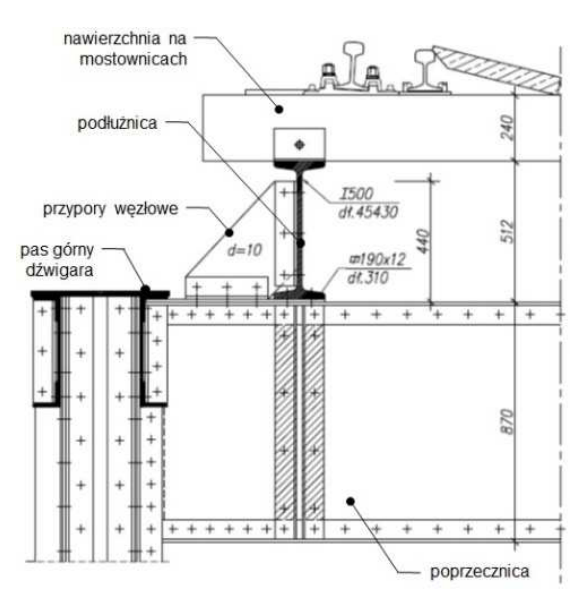

Rys. 5. Konstrukcja pomostu w przęsłach typu B przed remontem

Fig. 5. Deck structure in B-type span before renovation

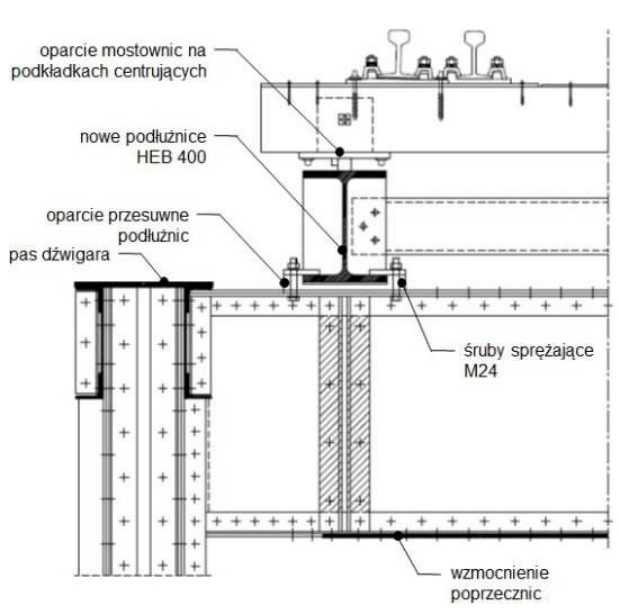

Rys. 6. Konstrukcja pomostu w przęsłach typu B po remoncie

Fig. 6. Deck structure in B-type span after renovation

\section{Sposób wykonania naprawy}

Modernizacja jezdni w przęsłach kratowych polegała na wzmocnieniu poprzecznic we wszystkich przęsłach nitowanych oraz poprzecznic skrajnych w przęsłach spawano-nitowanych, a także na całkowitej wymianie podłużnic wraz z układem stężeń i zmianie sposobu mocowania podłużnic do poprzecznic. Konieczność wzmocnienia poprzecznic $\mathrm{w}$ przęsłach nitowanych wynikała $\mathrm{z}$ ich nieprawidłowego ukształtowania, polegającego na braku blach pasowych, a w przypadku poprzecznic skrajnych również z ich niedostatecznej nośności. W przypadku przęseł spawano-nitowanych wzmocnieniu podlegały tylko poprzecznice skrajne z uwagi na brak nośności.

Aby wyeliminować opisany wyżej niekorzystny efekt pracy konstrukcji, polegający na silnej deformacji poziomej poprzecznic, zaprojektowano $\mathrm{w}$ ramach naprawy jezdni nowy sposób połączenia podłużnic z poprzecznicami, gwarantujący swobodę podłużnego przesuwu podłużnic (rys. 6.). Jedynie w części środkowej każdego dźwigara, na odcinku tężników hamownych połączenie podłużnic z poprzecznicami przyjęto nieprzesuwne (rys. 7.). Oparcie przesuwne podłużnic zaprojektowano jako stalowe łożysko liniowo styczne, składające się z dwóch części - dolnej wykonanej z jednolitego kęsa stalowego z odcinkiem środkowym wyfrezowanym do powierzchni łuku i części górnej, w postaci dwóch blach, przykręcanych do części dolnej po ustawieniu podłużnic (rys. 8.). Zadaniem części górnej jest przeniesienie ujemnych reakcji przekazywanych na miejsce oparcia podłużnicy od obciążeń ruchomych. Całość oparcia jest mocowana do poprzecznic za pomocą czterech śrub sprężających M24, a część dolna dodatkowo spawana do wzmocnionego pasa poprzecznicy. 


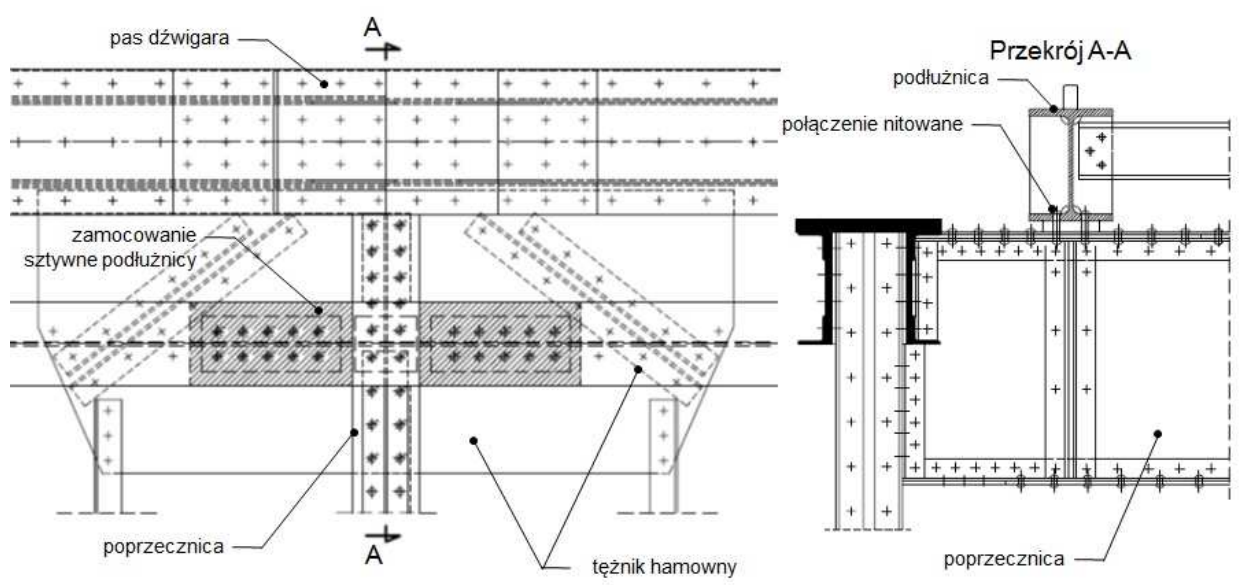

Rys. 7. Połączenie sztywne podłużnicy

Fig. 7. Rigid joint of stringers

Podłużnice zaprojektowano w postaci belek walcowanych HEB 400, stężonych poprzecznie za pomocą ceowników C200, które w rozstawie odpowiadającym, rozstawowi poprzecznic przyjęto zdwojone, a w polach pomiędzy poprzecznicami, zastosowano ceowniki pojedyncze. W miejscu połączenia podłużnic z ich stężeniami podłużnice wzmocniono pionowymi żebrami. Ceowniki są połączone z żebrami za pomocą nitów $\phi 20$. Na długości każdego przęsła podłużnica składa się z pięciu elementów wysyłkowych łączonych na moście montażowo za pomocą spoiny czołowej.
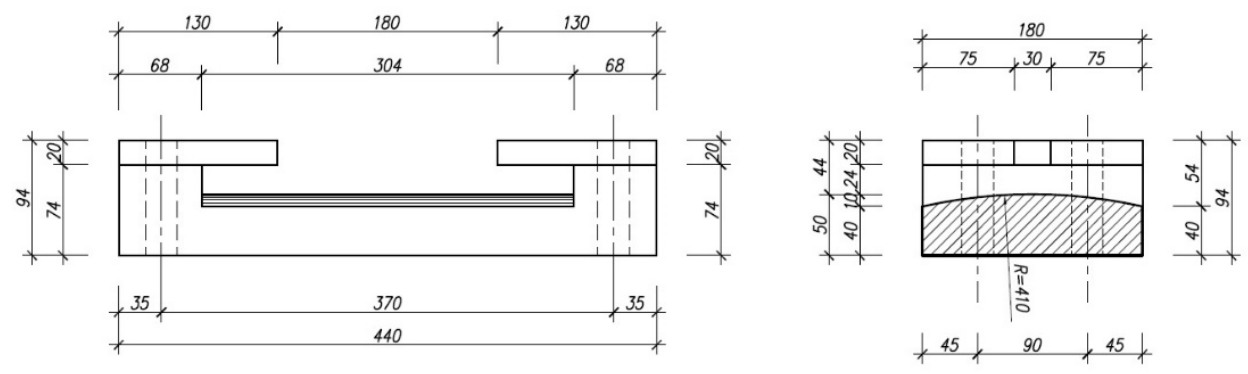

Rys. 8. Łożysko przesuwne poprzecznicy

Fig. 8. Sliding bearing of stringers

Oparcie mostownic na podłużnicach wykonano zgodnie z obowiązującymi przepisami [1] i [2] za pośrednictwem podkładek centrujących. Oparcie składa się ze stołeczków centrujących, podpórki wzmocnionej żebrem i blachy ślizgo- 
wej mocowanej do mostownic wkrętami. Wysokość stołków przyjmowano zmienną, tak aby umożliwić ułożenie jezdni $\mathrm{z}$ wyniesieniem odwrotnym od ugięcia dźwigara na skutek obciążeń użytkowych od taboru kolejowego.

W czasie oględzin przeprowadzanych przed remontem mostu stwierdzono znaczne skorodowanie wielu blach tężników hamownych. W czasie remontu, po rozebraniu elementów pomostu, okazało się, że w kilku blachach występują liczne pęknięcia zmęczeniowe (rys. 9.). Blachy takie zostały wymienione na nowe.

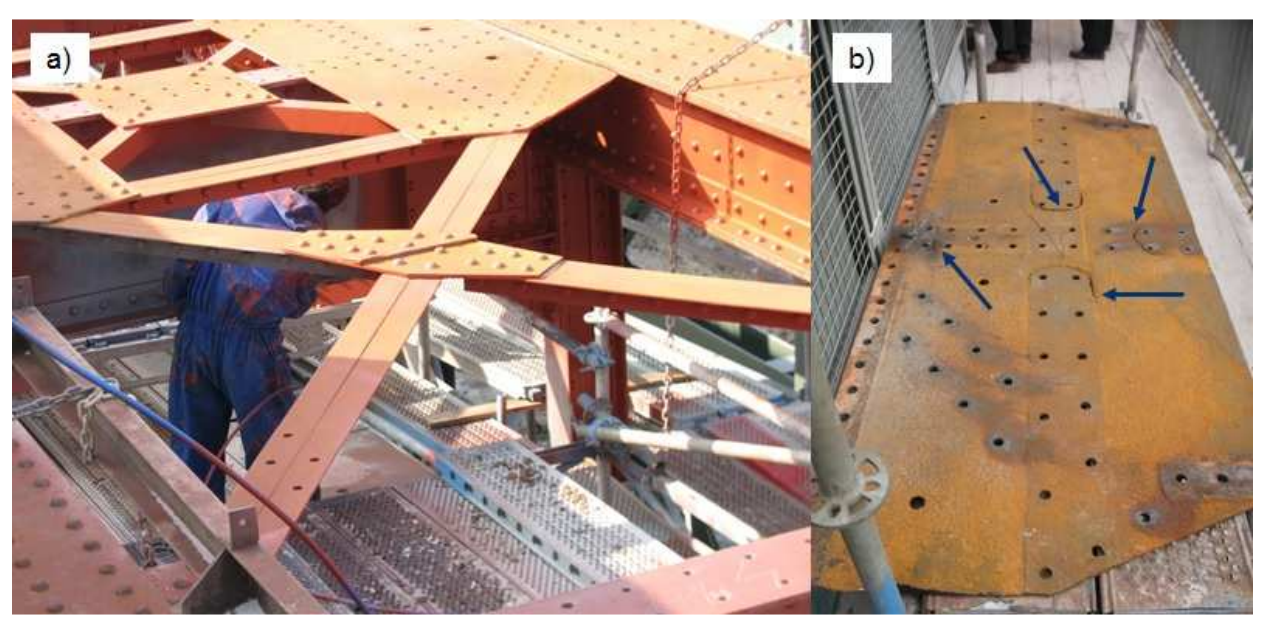

Rys. 9. Tężnik hamowny po odsłonięciu (a) i blacha tężnika z pęknięciami zmęczeniowymi (b)

Fig. 9. Braking girder after exposure (a) and plate of braking girder with fatigue cracking (b)

\section{Podsumowanie}

Wśród eksploatowanych obecnie stalowych mostów kolejowych licznie reprezentowane są kratownicowe konstrukcje z pomostem otwartym usytuowanym górą lub dołem, z podłużnicami opieranymi sztywno na poprzecznicach. Cechą charakterystyczną pracy statycznej tego typu obiektów, jest silna pozioma deformacja poprzecznic, spowodowana siłami poziomymi, pochodzącymi od różnicy wydłużeń dźwigarów głównych i podłużnic. Oddziaływania te przyczyniają się często do przeciążenia poprzecznic i do uszkadzania elementów pomostu. Zaprezentowany przykład mostu przez rzekę Wartę w Sieradzu ilustruje to zjawisko oraz wskazuje rozwiązania, pozwalające je wyeliminować. Zaprojektowane indywidualnie stalowe łożyska liniowo styczne umożliwiają swobodne podłużne odkształcenia podłużnic niezależne od odkształceń dźwigara i wyeliminowanie niekorzystnych oddziaływań poziomych. 


\section{Literatura}

[1] Standardy Techniczne. Szczegółowe warunki techniczne dla modernizacji lub budowy linii kolejowych do prędkości $\mathrm{V}_{\max } \leq 200 \mathrm{~km} / \mathrm{h}$ (dla taboru konwencjonalnego) / $\mathrm{V}_{\max } \leq 250 \mathrm{~km} / \mathrm{h}$ (dla taboru z wychylnym pudłem). Tom III - Kolejowe obiekty inżynieryjne, PKP PLK S.A., CNTK, Warszawa 2009.

[2] Warunki techniczne dla kolejowych obiektów inżynieryjnych Id-2, PKP PLK S.A., Warszawa 2005.

[3] Bień J.: Uszkodzenia i diagnostyka obiektów mostowych, Wydawnictwa Komunikacji i Łączności WKŁ, Warszawa 2010.

[4] Ryżyński A. i inni: Mosty stalowe, Wydawnictwo Naukowe PWN, Warszawa, 1985.

[5] Norma PN-S-10052:1982 Obiekty mostowe. Konstrukcje stalowe. Projektowanie.

\section{ASSESSEMENT OF THE REASONS AND REPAIR METHOD OF THE RAILWAY TRUSS BRIDGE DECK DEFECTS}

\section{S u m m a r y}

This article deals with issues related to the static work of floor beams in open-deck steel railway bridges. The problem of increased strain and deformation of floor beams from horizontal forces caused by the change of the length of the main girders and the braking force of the vehicles is presented. The example of a bridge over the Warta River in Sieradz is characterized by the characteristic damage to the bridge carriageway components and the way they are repaired, using individually designed steel bearings to enable the sliding support of the stringers on the cross members.

Keywords: truss bridge, sliding support of stringers, steel bearing

Przestano do redakcji: $28.04 .2017 \mathrm{r}$.

Przyjęto do druku: 01.09.2017 r. 